\title{
PERAN KEPALA SEKOLAH SEBAGAI MOTIVATOR DALAM MENINGKATKAN PROFESIONALISME KINERJA GURU DI SDN 2 KALIREJO PESAWARAN
}

\author{
Mulyatun Nikmah, Dedi Irawan, Aidil Azhar \\ Jl. Raya Wonokriyo Gading Rejo Pringsewu \\ Email: stitpringsewu@gmail.com
}

\begin{abstract}
This study aims to describe the role of principal as a motivator in improving the professionalism of teachers' performance in SDN 2 kalirejo pesawaran. Data collection is done by conducting observation, interview, and documentation. Data analysis used was qualitative descriptive analysis. The technique of checking the validity of the data used in this study is to use triangulation of sources, that is by comparing the data of observations with the data of interviews and comparing the results of interviews with the contents of a related document.

The results of the study show: The role of Headmaster as a Motivator in Improving Teacher Professionalism at SDN 2 Kalirejo Includes: the principal is able to create harmonious working relationships among teachers, able to create harmonious relationships among employees able to apply reward principles, Punishment), able to apply / develop internal and external motivation for school residents. The Role of School Principal As a Motivator in Improving Teacher Professionalism at SDN 2 Kalirejo has been running well, although in the implementation there are still many obstacles and obstacles in each component of madrasa management field.
\end{abstract}

\begin{abstract}
Abstrak
Penelitian ini bertujuan untuk mendeksripsikan tentang peran kepala sekolah sebagai motivator dalam meningkatkan profesionalisme kinerja guru di SDN 2 kalirejo pesawaran. Pengumpulan data dilakukan dengan mengadakan observasi, wawancara, dan dokumentasi. Analisis data yang digunakan adalah analisa kualitatif deksriptif. Adapun teknik pemeriksaan keabsahan data yang digunakan dalam penelitian ini yaitu menggunakan triangulasi sumber, yaitu dengan cara membandingkan data hasil pengamatan dengan data hasil wawancara dan membandingkan hasil wawancara dengan isi suatu dokumen yang berkaitan.

Hasil penelitian menunjukan: Peran Kepala Sekolah Sebagai Motivator dalam Meningkatan Profesionalisme Guru di SDN 2 Kalirejo Meliputi : kepala sekolah mampu menciptakan hubungan kerja yang harmonis sesama guru, mampu menciptakan hubungan yang harmonis sesama karyawan mampu menerapkan prinsip penghargaan (reward), mampu menerapkan prinsip hukuman (punishment), mampu menerapkan/mengembangkan motivasi internal dan eksternal bagi warga sekolah. Peran Kepala Sekolah Sebagai Motivator dalam Meningkatan Profesionalisme Guru di SDN 2 Kalirejo sudah berjalan dengan baik, walaupun dalam pelaksanaan masih banyak kendala maupun hambatan pada masing-masing komponen bidang manajemen madrasah.
\end{abstract}

Kata Kunci: Kepala Sekolah, Motivator, Profesionalisme Kinerja Guru. 


\section{A. PENDAHULUAN}

Tugas dan peran guru bukan saja mendidik, mengajar dan melatih tetapi juga bagaimana guru dapat membaca situasi kelas dan kondisi siswanya dalam menerima pelajaran. Untuk meningkatkan peranan guru dalam proses belajar mengajar dan hasil belajar siswa, maka guru diharapkan mampu menciptakan lingkungan belajar yang efektif dan akan mampu mengelola kelas.serta hal yang sangat mendukung kinerja guru dalam proses belajar mengajar adalah motivasi kepala sekolah yang sangat berpengaruh dalam berhasil tidaknya suatu sekolah tersebut,terutama dalam mendorong tercapainya profesionalisme guru agar proses belajar mengajar berlangsung dengan baik dan tercapai tujuan .

"Kepala sekolah merupakan salah satu komponen yang paling berperan dalam meningkatkan kualitas pendidikan,kepala sekolah merupakan pimpinan tunggal disekolah yang mempunyai tanggung jawab dan wewenang untukmengatur,mengelola, dan menyelenggarakan kegiatan disekolah,agar apa yang menjadi tujuan sekolah tercapai'".

Guru adalah pendidik profesional dengan tugas utama mendidik dan mengevaluasi peserta didik, pada pendidikan anak usia dini jalur pendidikan formal, pendidikan dasar dan pendidikan menengah.

Sementara pegawai dunia pendidikan merupakan bagian dari tenaga kependidikan, yaitu anggota masyarakat yang mengabdikan diri dan diangkat untuk menunjang penyelenggaraan pendidikan. kedisiplinan guru diartikan sebagai sikap mental yang mengandung kerelaan mematuhi semua ketentuan, peraturan dan norma yang berlaku dalam menunaikan tugas dan tangung jawab.

Dari pengertian diatas dapat disimpulkan, kedisiplinan guru dan pegawai adalah sikap penuh kerelaan dalam mematuhi semua aturan dan norma yang ada dalam menjalankan tugasnya sebagai bentuk tanggung jawabnya terhadap pendidikan anak didiknya.

Menurut T.Aritonang,kinerja adalah hasil kerja secara kualitas dan kuantitas yang dicapai oleh seorang pegawai dalam melaksanakan tugasnya sesuai dengan tanggung jawab yang diberikan kepadanya". Sedangkan guru adalah profesi yang secara professional berhadapan langsung dengan peserta didik.guru walaupun bukan satu-satunya faktor menentukan hasil dari proses pendidikan,maka bukan sebuah hiperbola jika terdapat pernyataan bahwa masa depan masyarakat, bangsa,dan Negara sebagian besar ditentukan oleh guru'. Oleh karena itu,penenangan yang paling tepat ialah melalui peningkatan motivasi kinerja.motivasi kinerja memiliki empat tahap : (1) penetapan standar kinerja ; (2) audit kerja ;(3) pemberian umpan balik secara langsung ; (4) motivasi kinerja ".

Corak kemanusiaan yang dibangun dalam rangka pembangunan nasional kita adalah "manusia Indonesia seutuhnya", yaitu manusia yang beriman dan bertaqwa kepada Tuhan Yang Maha Esa, percaya diri disiplin, bermoral dan bertanggung jawab. Untuk mewujudkan hal itu, keteladanan dari seorang guru sebagai pendidik sangat dibutuhkan. Keteladanan guru dapat dilihat dari prilaku guru sehari-hari baik didalam sekolah maupun diluar sekolah.

Selain keteladanan guru, kedisiplinan guru juga menjadi salah satu hal penting yang harus dimiliki oleh guru sebagai seorang pengajar dan pendidik. Fakta dilapangan yang sering kita jumpai disekolah adalah kurang disiplinnya guru, terutama masalah disiplin guru masuk kedalam kelas pada saat kegiatan pembelajaran dikelas. Peranan kepala sekolah didalam kemajuan pendidikan mempunyai pengaruh yang sangat besar karna didalam sekolah kepala sekolah yang memimpin serta mengembangkan potensi potensi yang ada didalam sekolah tersebut.

$$
\text { Dari segi kepemimpinan, }
$$

manajemen/administrasi dipengaruhi oleh pemimpin.pemimpin bisa seorang kepala sekolah,guru atau orang yang memimpin suatu kegiatan.jadi peran kepala sekolah sebagai motivator dalam meningkatkan profesionalisme guru sangat penting karena dengan adanya dorongan dari seorang pemimpin,maka kinerja guru akan semakin meningkat dan berhasil.

Kepala sekolah sebagai manajer dan pemimpin perlu memiliki kemampuan kepemimpinan yang prima demi organisasi yang dipimpinya.Aspek kunci peran kepemimpinan dalam pendidikan adalah memberdayakan guru untuk memberi mereka kesempatan secara maksimum guna mengembangkan belajar siswa. Semua pihak menyadari dan mengamini bahwa kinerja guru berbanding lurus dengan peningkatan mutu pendidikan.sayangnya, Tidak sedikit para guru bekerja dibawah standar kerja yang telah ditetapkan bukan karena tidak mampu tetapi karena belum terbangun budaya kerja yang baik.kondisi seperti itu disebabkan oleh rendahnya gairah kerja yang berdampak pada penurunan kinerja.

Dan didalam kinerja guru tentunya sangat membutuhkan motivasi atau dorongan dan arahan dari kepala sekolah seperti menggunakan metodemetode pembelajaran, menyusun rencana pelaksanaan pembelajaran yang berisi informasi yang tepat, mutakhir, dan yang membantu peserta didik, Serta melakukan pemetaan standar 
kompetensi dan kompetensi dasar untuk mata pelajaran yang diampunya.

\section{B. TUJUAN PENELITIAN}

Tujuan dalam penelitian ini adalah untuk mendeksripsikan peran kepala sekolah sebagai motivator di sdn 2 kalirejo, untuk mendeksripsikan profesionalisme kinerja guru di sdn2 kalirejo, untuk mendeksripsikan Peran kepala sekolah sebagai motivator dalam meningkatkan profesionalisme kinerja guru di sdn 2 kalirejo.

\section{METODE PENELITIAN}

Metode deskriptif bertujuan untuk membuat deskripsi, gambaran atau lukisan secara sistematis, faktual dan akurat mengenai fakta-fakta, sifat serta hubungan antar fenomena yang diselidiki.

Pengumpulan data dengan wawancara adalah cara atau teknik untuk mendaftarkan informasi atau data interviewee atau responden dengan wawancara secara langsung face to face, antara interviewer dengan interviewee.

\section{HASIL DAN PEMBAHASAN}

1) Analisis Peran Kepala Sekolah sebagai Motivator dalam Meningkatkan Profesionalisme Kinerja Guru di SDN 2 KALIREJO PESAWARAN

Penelitian ini mempunyi tujuan yaituUntuk mengetahui bagaimana Peran Kepala Sekolah sebagai Motivator dalam Meningkatkan Profesionalisme Kinerja Guru di SDN 2 Kalirejo kecamatan Negri katon Kabupaten Pesawaran. Untuk mencapai upaya tersebut maka dalam penelitian ini penulis memperoleh data dengan metode penelitian observasi, angket, wawancara, dan dokumentasi mengenai Motivasi Kepala Sekolah dalam Meningkatkan Profesionalisme Kinerja Guru di SDN 2 Kalirejo Pesawaran.

Dalam bab ini penulis mengelola data yang telah diperoleh untuk menentukan kesimpulan dari data-data tersebut. Kemudian yang harus dilakukan adalah mengelola data tesebut terutama data tentang Motivasi Kepala Sekolh dalam Meningkatkan Profesionalisme Kinerja Guru peningkatkan mutu pendidikan di SDN 2 Kalirejo Pesawaran.penulis juga sudah melakukan penyebaran angket dan wawancara untuk mengetahui sejauh mana selama ini Penerapan Motivasi yang dilakukan oleh kepala sekolah kepada para guru di SDN 2 Kalirejo Pesawaran sehingga dapat meningkatkan Kualitas Profesionalisme Kinerja Guru dalam Mendidik siswa siswi yang berkualitas dan mampu bersaing dengan sekolah-sekolah yang ada di kabupaten Pesawaran.
2) Pelaksanaan Motivasi Kepala Sekolah dalam Meningkatkan Profesionalisme Kinerja Guru di SDN 2 Kalirejo Pesawaran

Setiap Kepala Sekolah Memiliki Peranan Sebagai motivator untuk tenaga pendidik agar kinerjanya dapat ditingkatkan dan dipertanggungjawabkan sehingga menjadi berkualitas dan siswa siswi dapat meningkatkan prestasi belajar dan mampu menyerap serta mengembangkan ilmu yang diberikan para dewan guru dengan baik.

Kepala Sekolah SDN 2 Kalirejo Pesawaran sudah Menerapkan Peran sebagai Motivator dalam meningkatkan Profesionalisme Kinerja Guru di SDN 2 Kalirejo Pesawaran dengan baik diantaranya pengarahan dari Faktor eksternal dan faktor internal kinerja guru yaitu :

Faktor internal dari kepala sekolah SDN 2 Kalirejo Pesawaran :

Faktor internal kinerja guru adalah faktor yang datang dari dalam diri guru yang dapat memengaruhi kinerjanya, contohnya ialah kemampuan, keterampilan, kepribadian, persepsi, motivasi menjadi guru, pengalaman lapangan.

Dalam hal ini Kepala sekolah SDN 2 Kalirejo Pesawaran memberikan motivasi berupa sering mengadakan pelatihan-pelatihan antar sesama guru dan antar sekolah maupun didalam lingkungan sekolah itu sendiri,dengan tujuan untuk meningkatkan gairah kinerja guru agar lebih berkulitas sehingga dapat mencerdaskan siswa dan memajukan pendidikan di Indonesia khususnya menyukseskan proses belajar mengajar di sekolah.

Faktor eksternal dari kepala sekolah SDN2 Kalirejo Pesawaran :

(1) Gaji : Merupakan salah satu faktor penunjang kinerja guru yang diberikan oleh kepala sekolah dari pemerintah setempat.

(2) sarana dan prasarana; kepala sekolah sudah memberikan sarana dan prasarana sebagai penunjang proses pembelajaran, akan tetapi kurangnya sarana dan prasarana yang memadai menjadi penghambat proses pembelajaran yang berkualitas baik dari segi pengajarannya maupun siswa yang menerima ilmu dan pelajaran yang kurang sepenuhnya,hal ini disebabkan karena keterbatasan dana dari kepala sekolah dalam pengelolaannya.dibawah ini diantaranya sarana dan prasarana yang sudah disediakan kepala sekolah di SDN 2 Kalirejo pesawaran

SDN 2 Kalirejo Pesawaran memiliki 3 unit gedung dengan 6 buah ruang belajar, 1 buah kantor, dan 1 buah perpustakaan. Semua bangunan tersebut milik sendiri dan 
permanen dengan kondisi yang masih sangat baik. Sedangkan sarana dan prasarana kegiatan belajar mengajar antaralain berupa buku-buku pelajaran, alat bantu pengajaran, dengan perincian sebagai berikut:

(3) lingkungan kerja fisik; kepala sekolah menciptakan lingkungan kerja yang nyaman dan kekeluargaan sehingga berbagai kritik dan saran dari dewan guru maupun kepala sekolah itu sendiri mudah diutarkan, hal ini dikarenakan kepala sekolah sering mengadakan rapat serta menjalin komunikasi yang baik antar sesame guru.

(4) kepemimpinan ; kepemimpinan kepala sekolah SDN 2 Kalirejo Pesawaran menggunakan system demokratis sehingga memudahkan jalan keluar dalm menghadai berbagai masalah dan persoaln yang dihadapi kepala seklah dan para dewan guru. Dalam kepemimpinan kepala sekolah yang berperan sebagai motivator dalam meningkatkan profesionalisme kinerja guru di SDN 2 Kalirejo Pesawaran,kepla sekolah memberikan reward bagi guru yang dinilai berhasil dan bertanggung jawab dalam melaksanakan tugasnya dan memberikan punishment kepada guru yang dianggap kurang bertanggung jawab dalm melaksanakan tugasny dan dianggap tidak disiplin.

Hasil observasi diatas menunjukkan bahwa pengelolaan kurikulum telah dilakukan dengan cukup baik dibuktikan dengan tersedianya silabus untuk setiap mata pelajaran dan Rencana Pelaksanaan Pembelajaran (RPP) yang telah memuat tujuan pembelajaran secara tepat, materi yang sesuai dengan tujuan pembelajaran, strategi pembelajaran yang variatif, meskipun strategi tersebut belum mengarah pada kelompok atau perorangan dengan baik. Metode pembelajaran juga sudah direncanakan dengan cukup baik yaitu dengan menerapkan metode yang variatif, walaupun belum mengarah pada pembelajaran yang aktif, kreatif, inovatif dan menyenangkan. Demikian pula dengan perencanaan penilaian yang sudah mencatumkan semua aspek penilaian, yaitu aspek kognitif, afektif dan psikomotor dalam bentuk penilaian tertulis dan kinerja.

Pada pengelolaan kurikulum dalam pelaksanaan pembelajaran di SDN 2 Kalirejo Pesawaran Kecamatan Negri Katon Kabupaten Pesawaran, Sekolah diberi kewenangan untuk mengembangkan kurikulum yang sudah diterapkan oleh pemerintah namun tidak diperbolehkan untuk mengurangi isi kurikulum yang sudah berlaku secara nasional. Di dalam program penyusunan administrasi pembelajaran harus sesuai dengan struktur isi kurikulum, oleh karena itu semua pendidik di SDN 2 Kalirejo
Pesawaran Kecamatan Negri Katon Kabupaten Pesawaran harus dapat mempersiapkan administrasi pembelajaran yang ditekankan harus lengkap, dan setiap guru mempersiapkan untuk membuat perangkat pembelajaran mulai dari membuat prota, promes, silabus dan Rencana Pelaksanaan Pembelajaran (RPP). Yang semua itu tidak terlepas dari kalender pendidikan yang sudah diberikan dan semua itu juga ketetapan dari pusat.

Berdasarkan hasil observasi di atas, diketahui bahwa pengelolaan tenaga pendidik dan kependidikan telah dilaksanakan dengan cukup baik, artinya mengalami peningkatan setiap tahunnya, dibuktikan dengan tersedianya sistem penerimaan, penempatan, penilaian kinerja dan pengembangan sumber daya manusia, promosi dan demosi, pengembangan kompetensi, peningkatan kualifikasi, pengadiministrasian personalia dan pendataan. Hasil observasi di atas selaras dengan hasil wawancara dengan kepala madrasah dan guru SDN 2 Kalirejo Pesawaran Kecamatan Negeri Katon Kabupaten Pesawaran yang menyatakan bahwa dalam meningkatkan kinerja guru dalam melaksanakan proses belajar mengajar dilakukan bimbingan-bimbingan dan pelatihan dengan tujuan para tenaga pendidik yang ada di SDN 2 Kalirejo Pesawaran Kecamatan Negri Katon Kabupaten Pesawaran dapat melaksanakan program pembelajaran dengan baik, dapat membuat perangkat-perangkat pembelajaran seperti, Rencana Pelaksanaan Pembelajaran (RPP), Program Tahunan (Prota), Program Semester (Promes), kisi-kisi soal, dan dapat melakukan program perbaikan dan pengayaan.

Sekolah juga mengirimkan guru-guru untuk mengikuti kegiatan-kegiatan Musyawarah Guru Mata Pelajaran (MGMP), penataran-penataran, seminar, workshop maupun pelatihan-pelatihan lainnya secara bergantian guna menambah wawasan dan pengetahuan mereka dalam pelaksanaan proses pembelajaran di samping itu madrasah pun memberi kesempatan kepada tenaga pendidik untuk meningkatkan kualifikasinya dengan melanjutkan studi ke jenjang yang lebih tinggi.

Berdasarkan hasil observasi di atas, diketahui bahwa pengelolaan kesiswaan telah dilaksanakan dengan cukup baik, dibuktikan dengan tersedianya sistem penerimaan, penilaian dan pengembangan, pembinaan dan pembimbingan, tindak lanjut/evaluasi, pembentukan karakter, dan pendataan. Hasil observasi di atas selaras dengan hasil wawancara dengan kepala Sekolah dan waka kesiswaan SDN 2 Kalirejo Pesawaran 
Kecamatan Negri Katon Kabupaten Pesawaran dyang menyatakan bahwa dalam pengelolaan kesiswaan telah dibentuk kebijakan dalam penerimaan siswa didik baru antara lain dengan membuat beberapa kriteria tes masuk, Pengelolaan siswa tidak sampai itu saja, tetapi sekolah terus berupaya untuk mengembangkan potensi dan meningkatkan prestasi siswa melalui KBM dan kegiatan ekstrakurikuler lainnya pelaksanaan penerimaan penilaian tindak lanjut/evaluasi serta bimbingan dan pembinaan siswa, dapat membuat di sekolah kami terlebih untuk mengembangkan potensi yang ada pada peserta didik dengan harapan madrasah mampu mengeluarkan mutu siswa dengan bernilai Plus di banding sekolah umum di sekitar lingkungannya.

\section{a. Pengelolaan Sarana prasarana}

Sarana dan prasarana pendidikan SDN 2 Kalirejo kecamatan Negri Katon Kabupaten Pesawaran sudah cukup layak dan bisa dikatakan jauh dari sempurna tapi yang masih menjadi problem disini:

1. Belum tersedianya ruang bimbingan dan konseling (BK), yang memadai. Hal ini berdasarkan wawancara peneliti dengan informan di bawah ini:

"Pada kepemimpinan saya ini untuk masalah sarana dan prasarana sudah bisa dikatakan cukup memuaskan, Cuma saya merasa kekurangan pendanaan di dalam Kegiatan Ekstra kulikuler beserta mendatangkan orang bertanggung jawab di dalamnya". (Masyani, S.Pd.SD, Kepala SDN 2 Kalirejo, Wawancara, tgl. 14 Juli 2016)

2. Belum terpenuhinya buku-buku mata pelajaran di perpustakaan artinya hanya sebagian buku mata pelajaran sebagai bahan siswa dalam pembelajaran. Hal ini berdasarkan wawancara peneliti dengan salah satu informan di bawah ini:

"SDN 2 Kalirejo Kecamatan Negri Katon Kabupaten Pesawaran ini belum mempunyai banyak buku persediaan di perpustakaan Sekolah, oleh karena itu untuk tahun pelajaran berikutnya masih diusahakan bisa terselesaikan pada tahun pelajaran baru ". (Masyani, S.Pd.SD, Kepala SDN 2 Kalirejo, Wawancara, tgl. 16 Juli 2016)

Berdasarkan paparan di atas, maka diperoleh temuan bahwa sarana dan prasarana SDN 2 Kalirejo Pesawaran Kecamatan Negri Katon Kabupaten Pesawaran meliputi: belum terpenuhinya sarana prasarana kegiatan ekstra kulikuler yang memadai dan belum terpenuhinya buku mata pelajaran siswa di perpustakaan madrasah. Namun meskipun demikian tidak ada hambatan dalam proses pengembangannya meskipun rintangan dan bahkan para personil madrasah masih memiliki sikap optimis yang tinggi untuk selalu mengembangkan madrasahnya menuju kearah yang lebih baik dan mapan.

Dalam pelaksanaan Peran Kepala Sekolah sebagai Motivator dalam Meningkatkan Kinerja Guru di SDN2 Kalirejo, Kecamatan Negri Kaaton Kabupaten Pesawaran diantaranya Melaksanakan Supervisi kepada Dewan Guru dan mendorong serta mendukung berbagai Kegiatan yang diadakan Sekolah berdasarkan Keputusan bersama yang diadakan rapat Sebelumnya Contohnya Kegiatan Pramuka, Bimble yang Sudah berjalan dengan baik dan memberikan peraturan tentang kedisiplinan serta memberikan reward kepada dewan guru yang bekerja dengan sangat baik dan punishment kepada guru jika melakukan kesalahan disengaja . (Masyani, S.Pd.SD, Kepala SDN 2 Kalirejo, Wawancara, tgl. 16 Juli 2016).

\section{Faktor Pendukung dan Penghambat Peran Kepala Sekolah sebagai Motivator dalam Meningkatkan Kinerja Guru di SDN2 Kalirejo, Kecamatan Negri Kaaton Kabupaten Pesawaran}

Suatu program yang dilaksanakan pada setiap Sekolah dapat berhasil atau tidak bisa diukur dengan adanya faktor pendukung dan penghambat.

Berkaitan dengan hal tersebut di atas berikut hasil wawancara dengan kepala madrasah:

a. Faktor pendukung

Faktor pendukung dalam melaksanakan

Peran Kepala Sekolah sebagai Motivator dalam Meningkatkan Kinerja Guru di SDN2 Kalirejo, Kecamatan Negri Katon Kabupaten Pesawaran adalah dengan adanya kerja sama kepala sekolah, wakamad, waka kurikulum, TU, komite madrasah dan guru secara efektif dan kompak dari mulai diadakan rapat perencanaan sampai pada pelaksanaan dan evaluasi. Sementara faktor penghambat dalam pelaksanaan Peran Kepala Sekolah sebagai Motivator dalam Meningkatkan Kinerja Guru di SDN2 Kalirejo, Kecamatan Negri Katon Kabupaten Pesawaran, kami akui masalah keuangan adalah faktor utama yang belum terselesaikan. Namun kami telah berupaya mencari solusi terkait hal tersebut. (Hasil Wawancara dengan 
Kepala Sekolah (Senin, 14 Juli 2016, Pukul 08.00-09.00 WIB).

Adanya kerjasama dan kekompakan antara pihak Sekolah (kepala sekolah, Dewan Guru,Staff TU dan komite sekolah serta Masyarakat) Pada setiap bidang pengelolaan kurikulum, pengelolaan ketenagaan (guru), pengelolaan kesiswaan, pengelolaan sarana prasarana, pengelolaan keuangan, serta hubungan Sekolah dan masyarakat. Telah dilaksanakan dengan cukup baik sesuai dengan program kerja pada pelaksanaan Peran Kepala Sekolah sebagai Motivator dalam Meningkatkan Kinerja Guru di SDN2 Kalirejo, Kecamatan Negri Kaaton Kabupaten Pesawaran.Walaupun masih ada beberapa bidang pengelolaan yang belum memadai.

b. Faktor Penghambat

Berdasarkan hasil analisis data yang disajikan, ditemukan data pada pengelolaan keuangan sekolah belum memadai yang merupakan faktor utama dalam pelaksanaan Peran Kepala Sekolah Sebagai Motivator Dalam Meningkatkan Profesionalisme Kinerja Guru di SDN 2 Kalirejo Pesawaran Sehingga hal tersebut harus diselesaikan.

\section{E. PENUTUP}

1) Kesimpulan

Motivasi Kinerja digunakan untuk Menangani rendahnya Semangat dan Gairah Kinerja.Motivasi Kinerja merupakan Upaya untuk Meningkatkan Profesionalisme Kinerja Guru di SDN 2 Kalirejo.

Dua Faktor Pendukung Peran Kepala Sekolah Sebagai Motivator dalam Meningkatkan Profesionalisme Kinerja Guru di SDN 2 Kalirejo :

a. Faktor pemuas kinerja yang bersumber dari dalam diri seseorang antara lain:1) prestasi Kinerja guru SDN 2 Kalirejo yang diraih, 2)pengakuan para Dewan Guru, 3) tanggung jawab, 4) Peluang untuk Maju, 5)Kepuasan Kerja itu Sendiri, 6) Kemungkinan Pengembangan Kinerja Guru.

b. Faktor Pemelihara yang Merupakan tempat Pemenuhan Kebutuhan Tingkat Rendah dikualifikasikan kedalam Faktor ekstrinsik, Meliputi (1) Kompensasi untuk Guru, (2) Keamanan dan

Keselamatan, (3) Kondisi Kinerja, (4) status, (5) Prosedur Peratura Sekolah, (6) Mutu dari Supervisi Kepala Sekolah serta Pengawas dan hubungan interpersonal di antara teman sejawat, dengan atasan, dan dengan guru.

Meliputi (1) Kompensasi untuk

Guru, (2) Keamanan dan Keselamatan, (3) Kondisi Kinerja, (4) status, (5) Prosedur Peratura Sekolah, (6) Mutu dari Supervisi Kepala Sekolah serta Pengawas dan hubungan interpersonal di antara teman sejawat, dengan atasan, dan dengan guru.

\section{2) Saran}

Kepala SDN 2 Kalirejo Kecamatan Negri Katon Kabupaten Pesawaran dapat menggunakan hasil penelitian ini sebagai bahan untuk terus mengembangkan manajemen yang sehat sesuai dengan tujuan diterapkannya Peran Kepala Sekolah Sebagai Motivator dalam Meningkatkan Profesionalisme Kinerja Guru di SDN 2 Kalirejo Pesawaran sehingga kehadiran madrasah ini dapat memberikan kontribusi yang positif bagi kemajuan lingkungan di sekitarnya.

Peranan guru dalam proses belajar mengajar sangat berpengaruh terhadap keberhasilan peserta didik sehingga diharapkan guru-guru SDN 2 Kalirejo Kecamatan Negri Katon Kabupaten Pesawaran Kecamatan Negri Katon Kabupaten Pesawaran dapat lebih mengembangkan kompetensinya dalam melaksanakan pembelajaran, agar proses belajar mengajar dapat mencapai hasil yang diharapkan.

Agar masyarakat Kalirejo dan sekitarnya dapat lebih berperanserta aktif dalam membantu mewujudkan visi dan dan misi madrasah meningkatkan mutu pendidikan di madrasah ini, Dengan terjalinnya kerjasama yang erat antara sekolah dan masyarakat diharapkan SDN 2 Kalirejo Kecamatan Negri Katon Kabupaten Pesawaran dapat menjadi madrasah yang disegani dan diperhitungkan serta menjadi pilihan utama bagi masyarakat yang ingin menyekolahkan putra-putri mereka di lembaga Sekolah. 


\section{DAFTAR PUSTAKA}

Abdurrahmat Fathoni, 2006, Manajemen Sumber Daya Manusia, Bandung:Rineka Cipta.

Andang, manajemen \& kepemimpinan kepala sekolah,Yogyakarta:Ar-ruzz media,2014 cet ke-I

Barnawi \& Muhammad Arifin,kinerja guru professional,Yogyakarta: ar-ruzz media, 2014 cet ke-II

Darwis Amri, 2014, Metode Penelitian Pendidikan Islam, Jakarta : PT Raja Grafindo

Himat, 2009, Manajemen Pendidikan, Bandung : Pustika Setia.

Jogiyanto, 2008, Metode Penelitian Sistem Informasi, Jogyakarta : CV Andi Offset

Jusuf, 2012, Pengantar Metode Penelitian, Jakarta : Mitra Wacana Media.

Karwati Euis, 2013, Kinerja dan Profesionalisme Kepala Sekolah, Bandung : Alfabet

Nazir,M,Metode penelitian Jakarta,ghalia Indonesia, 2003

Rohiat, manajemen sekolah, bandung : PT Refika aditama 2012 cet ke IV

Saefullah, 2012. Manajemen Pendidikan Islam. Bandung: Pustaka Setia.

Sanapiah faisal, penelitian kualitatif dasar-dasar aplikasi, malang :IKIP , 1990

Schunk, D.H.,P.R. pintrick \& J.L.Meece.2010.motivation in education

theory, research, and application, upper saddler river. New jersey : pearson Merrill prentice hall.

Shabir Muslich, 2004, Terjemah Riyadus Shalihin, Semarang : PT Karya Toha Putra.

Soetopo Hendyat \& Soemanto Wasty, 1993, Pembinaan dan Pengembangan Kurikulum Sebagai Subtansi Problem Administrasi Pendidikan, Jakarta : PT. Bumi Aksara.

Suharsimi arikunto, prosedur penelitian suatu pendekatan praktek, Jakarta,Rineka Cipta, 2002.

Sugiyono, metode penelitian kuantitatif kualitatif dan $R$ \& $D$,bandung : ALFABETA 2009 ,cet.ke 8 .

Sugiyono, 2015, Metode Penelitian Pendidikan, Bandung : Alfabet

Suryana Asep, dan suryadi, Pengelolaan Pendidikan, Jakarta : direktorat Jendral Pendidikan islam Departemen Agama RI.

Suryosubroto, 2004, Manajemen Peningkatan Mutu Berbasis Madrasah, Semarang : PT Pustika Rizki Putra.
Sutrisno hadi, metodologi research, jilid I, Yogyakarta :UGM press, 1986.

Team Redaksi Sinar Grafika, 2006, Undangundang Permendiknas Tentang S1 dan SKL, Jakarta : Sinar Grafika.

Tim Penyusun Kamus Pusat Pembinaan dan Pengembangan Bahasa, Kamus Besar Indonesia, Jakarta Balai Pustaka, 1990.

Usman husaini, manajemen, Jakarta : PT Bumi aksara, 2013 cet ke-IV

Yamin martinis dan maisyah, standarisasi kinerja guru, Jakarta : gunung persada (gp press), 2010,cet.ke-I 